\title{
Carcass characteristics of feedlot-finished Zebu and Caracu cattle ${ }^{1}$
}

\section{Flávio Dutra de Resende ${ }^{3}$, Antonio Gesualdi Júnior², Augusto César de Queiroz², Marcelo Henrique de Faria ${ }^{3}$, Alexandre Pio Viana ${ }^{4}$}

\author{
${ }^{1}$ Research financed by FAPESP. \\ ${ }^{2}$ Universidade Federal de Viçosa, Viçosa, MG, Brasil. \\ ${ }^{3}$ APTA Regional Alta Mogiana, Colina, SP, Brasil. \\ ${ }^{4}$ Universidade Estadual do Norte Fluminense Darcy Ribeiro, Campos dos Goytacazes, RJ, Brasil.
}

\begin{abstract}
This study analyzes the chemical carcass characteristics and carcass losses in 86 cattle, both castrated and non-castrated, with an average initial weight of $329 \mathrm{~kg}$ and an average age of approximately 20 months, including $12 \mathrm{Gyr}, 20$ Guzerat, 20 Nellore, and 20 Caracu among the herds selected for weight determination at 378 days of age, as well as 14 Nellore cattle that were not selected. The diet contained a roughage-to-concentrate ratio of 60:40 in terms of dry matter (DM), with $14.8 \%$ crude protein as a percentage of DM and corn silage as roughage. A completely randomized $5 \times 2$ factorial experimental design was used, including five breeds and two sex classes. The following values were determined: losses due to the trimming of commercial cuts and cooking; shear force; the temperature and $\mathrm{pH}$ of the meat; and the chemical composition of the Hankins and Howe section (HH section). The castrated animals exhibited greater losses from the front trimmings compared with the non-castrated cattle. There were no differences in the final $\mathrm{pH}$ values of the carcasses among the breeds, although the noncastrated animals exhibited higher values than the castrated ones, likely because non-castrated animals were more susceptible to stress. The final $\mathrm{pH}$ remained within the range considered optimal for all of the carcasses studied. No differences were observed in the shear force among the breeds or between the two sexes. When appropriately managed, zebu breeds are capable of producing tender meat, thus meeting the demands of the consumer market.
\end{abstract}

Key Words: feedlot, meat quality, shear force, Zebu cattle

\section{Introduction}

Currently, most of the cattle breeds raised in Brazil have the potential to produce carcasses that meet the minimum classifications desired by slaughterhouses, with the exception of small-size heifers and steers.

Fat is important up to the point of providing the fat cover of an animal, resulting in a better-quality carcass. However, as it is considered a byproduct, excess fat increases the cost of meat for the consumer and requires more cleaning of carcasses prior to weighing and paying the producer.

Another important factor in meat production is the preservation of the carcass after slaughter. The conventional processing of cattle carcasses includes refrigeration immediately after slaughter to achieve a temperature of approximately $7{ }^{\circ} \mathrm{C}$ in the muscular mass before the meat is processed or brought to market. This cooling is aimed at ensuring the hygienic-sanitary safety of the product, though it may result in excessive contraction of the sarcomeres, resulting in tougher meat.

The events that occur in the carcass after slaughter, such as the decline in $\mathrm{pH}$ and temperature, are closely related to the meat quality (Resende et al., 2002), because the capacity to retain water is influenced by these aspects. Water retention, in turn, is what maintains the juiciness of meat and reduces nutrient losses. Therefore, temperature and $\mathrm{pH}$ should be maintained at values such that the quality of the final product provided to the consumer is maintained.

The Brazilian researchers must strive to develop studies related to the post mortem period in cattle, since the largest slaughterhouse companies in the world are now located in Brazil, while it is believed that the product that is sold still needs to achieve a better quality. When this objective is met, the profits from exportation may be greater, without necessarily implying increases in the sizes of cattle herds or the number of carcasses sold.

This study was developed with the objective of determine the losses due to the trimming of commercial cuts; the losses due to cooking-evaporation and dripping; the shear force, temperature, and $\mathrm{pH}$ of the meat; and the chemical composition of the Hankins and Howe section (HH section) of animals of five breeds: Gyr, Guzerat, Nellore, and Caracu, selected for weight determination at 378 days of age, and unselected Nellore cattle, including castrated and non-castrated sexual conditions. 


\section{Material and Methods}

A total of 86 animals with an initial average age of 19.8 months, from the 18th progeny of Gyr (12), Guzerat (20), Nellore (20), and Caracu (20) herds selected for weighing at 378 days of age and a Nellore (14) herd that did not undergo selection, were used. The animals were obtained at the end of a weight gain test in 1999 performed at Sertãozinho, state of São Paulo, Brazil, following the criteria described by Razook et al. (1997). Half of the animals from each breed were castrated immediately after the final weight gain test in October 1999. After an adaptation period, confinement began, and the animals were randomly paired according to their breed and sexual category in pens with total areas of $30 \mathrm{~m}^{2}$, with $8 \mathrm{~m}^{2}$ of covered area and concrete feeders and drinkers.

The experimental diet contained $148.0 \mathrm{~g} / \mathrm{kg} \mathrm{DM}$ of crude protein $(\mathrm{CP})$ and had a roughage-to-concentrate ratio of 60:40 in terms of dry matter. The experimental ratio was calculated based on the nutritional requirements proposed by the National Research Council (1996) for an estimated live weight gain of $1.0 \mathrm{~kg} /$ animal/day (Table 1 ). The feed was provided ad libitum twice daily at $07.00 \mathrm{~h}$ and $16.00 \mathrm{~h}$.

Samples of foods offered were collected weekly for chemical analysis (Table 2). The contents of moisture, crude protein $(\mathrm{CP})$, neutral detergent fiber, ether extract (EE) and ash (MM), were determined according to methods described by Silva and Queiroz (2002).

At the beginning of the experiment and at 28 day intervals, the animals were weighed after fasting for 18 hours, and the thicknesses of the subcutaneous fat cover and the loin-eye area were monitored by ultrasound in real time. The equipment used was an ALOKA 500V (Corometrics Medical Systems, Inc., Wallingford, CT) with a $3.5 \mathrm{MHz}$ transducer of $17 \mathrm{~cm}$ in length, specifically developed to collect images in animals (Izquierdo et al., 2000). The animals were slaughtered when the average thickness of the subcutaneous fat of the animals per pen reached $4 \mathrm{~mm}$.

The animals to be slaughtered were not given feed or water for at least 18 hours prior to weighing, and they were

Table 1 - Proportions of the ingredients in the concentrate mixture

\begin{tabular}{lc}
\hline Ingredients & Content $(\mathrm{g} / \mathrm{kg}$ as fed $)$ \\
\hline Ground corn & 767.0 \\
Cottonseed meal & 190.0 \\
Urea & 18.0 \\
Limestone & 15.0 \\
Mineral mixture & 10.0 \\
\hline
\end{tabular}

sent to a commercial slaughterhouse after their weights were obtained. After being confined, each animal was rendered unconscious by brain stunning and then hung for subsequent bleeding by jugular venipuncture. The carcasses were then divided in half and weighed to determine the hot carcass weight. The hot half carcasses were subsequently transferred to a refrigeration chamber, where they remained for 24 hours, at which point they were weighed again.

After being refrigerated for 24 hours, the right half carcasses were separated into the following primal cuts: pistol style cut, short ribs, and forequarter (five ribs).

A cut between the 9th and 11th ribs (HH section) was removed according to the methodology proposed by Hankins and Howe (1946), and the muscles, fat, and bones were mechanically separated, and weighed. The HH section was ground after mechanical separation, and a sample was removed and stored. The samples of the HH section were properly identified, freeze dried, ground with dry ice, packaged, and stored in a freezer. Chemical analysis of the meat was performed in these samples, including the $\mathrm{CP}, \mathrm{EE}$ and MM according to Silva and Queiroz (2002).

In the pistol style cut primal cuts obtained from the right half carcasses after 24 hours of refrigeration, the $\mathrm{pH}$ and temperature values were measured for the top round and sirloin cuts with an 1120-X pH meter (Mettler Toledo).

The losses due to trimming were determined after boning the primal cuts, including the forequarter, shoulder, and pistol style cut, using the difference in weight between the dirty (without fat trimmings removed) and clean (after the removal of excess fat to comply with the domestic market standard of a fat thickness of $3 \mathrm{~mm}$ ) commercial cuts, expressed as a percentage of the weight of each commercial cut and of the weight of the right half carcass.

A qualitative analysis of the meat was performed by measuring the shear force and the losses due to cooking of sirloin samples removed between the 12th and 13th ribs. The shear force was measured on a Warner-Bratzler Shear device with a $25 \mathrm{~kg}$ capacity.

A completely randomized $5 \times 2$ factorial (breed and sex) experimental design was adopted. The data were statistically interpreted using analysis of variance with

Table 2 - Chemical composition ${ }^{1}$ of concentrate and corn silage

\begin{tabular}{lcccc}
\hline Nutrient & $\begin{array}{c}\text { Concentrate } \\
\text { mixture }\end{array}$ & $\begin{array}{c}\text { Cottonseed } \\
\text { meal }\end{array}$ & $\begin{array}{c}\text { Ground } \\
\text { corn }\end{array}$ & $\begin{array}{c}\text { Corn } \\
\text { silage }\end{array}$ \\
\hline Dry matter $(\mathrm{g} / \mathrm{kg})$ & 812.1 & 818.7 & 794.5 & 310.3 \\
Crude protein $^{1}$ & 246.0 & 409.8 & 109.4 & 82.6 \\
Neutral detergent fiber $^{1}$ & 173.1 & 332.3 & 121.1 & 478.5 \\
Ether extract $^{1}$ & 13.0 & 6.2 & 2.8 & 28.1 \\
Mineral matter $^{1}$ & 32.5 & 53.9 & 11.4 & 43.6 \\
\hline${ }^{1} \mathrm{~g} / \mathrm{kg} \mathrm{DM}$. & & & &
\end{tabular}


F test at a $5 \%$ probability, and the means were compared using a least significant difference (LSD) test at a $5 \%$ probability. The general linear models (GLM) procedure in SAS (Statistical Analysis System, version 8.9) was used for both tests.

\section{Results and Discussion}

The losses due to the trimming of the pistol style cut and the commercial rump cuts (prime rib, skirt, and shank) revealed an interaction between the breed and the sexual condition. There was no interaction for the remaining variables. Therefore, these two effects were considered to be independent.

There was a difference in the total losses due to the trimming of the pistol style cut among breeds, but only for non-castrated animals. The unselected and selected Nellore animals exhibited the greatest loss percentages, of 5.38 and $5.35 \mathrm{~kg} / 100 \mathrm{~kg}$ of carcass, respectively. This effect was probably due to the greater accumulation of fat in these breeds (Table 3). It was also observed that castrated Caracu cattle had greater losses than the non-castrated individuals of this breed (Table 3).

The breed and sexual condition had an effect on the losses from the forequarters. The Caracu breed and the noncastrated sexual category were associated with the smallest losses, likely due to the lesser accumulation of fat in these animals (Table 4).

Note that the data provided above regarding the cleanliness of the cuts and, consequently, the percentage of losses due to trimming may not be very reliable measurements due to the lack of standardization of the procedure, given that it was performed by employees of a commercial slaughterhouse following their internal procedures and by several employees at the same time. Therefore, there could have been incorrect removal of intermuscular fat from any of the commercial cuts by one employee compared with the others. However, at first, this source of variation (or possibility of error) was the same for all of the cuts and animals in question. To minimize the sources of variation, a procedure was adopted in which the trimmings had to be removed to meet the standards of the domestic market.

When the literature was reviewed, no suitable studies were identified for comparison, though the results demonstrate the need to evaluate the losses due to trimming, which may lead to greater costs for commercial cuts if the losses are excessive. The minimum amount of fat cover is the cover that provides protection of the carcass during the refrigeration process (Luchiari Filho, 2000) and minimizes losses during "cleaning" of the carcass. In addition, excess fat decreases the feed conversion efficiency during the finishing process.

There was no difference among the breeds regarding the temperature values for top round and the sirloin (Table 5). The temperatures obtained were between 7.56 and $8.7{ }^{\circ} \mathrm{C}$ for top round and 7.41 and $8.02{ }^{\circ} \mathrm{C}$ for sirloin. The temperatures obtained were higher than the values found by Costa et al. (2012).

However, the cuts from the non-castrated animals exhibited higher temperatures than those from the castrated cattle after 24 hours of refrigeration.

In the refrigeration process, the carcass is refrigerated immediately after slaughter to achieve a temperature of approximately $7{ }^{\circ} \mathrm{C}$ in the muscular mass of the meat before the meat can be processed and sold. The purpose of this refrigeration is to ensure the hygienic-sanitary safety of the product, although it may result in excessive

Table 3 - Least squares means for the total losses in $\mathrm{kg} / 100 \mathrm{~kg}$ of carcass, from trimmings of the pistol style cut relative to the carcass weight for the different breeds and sexual conditions

\begin{tabular}{|c|c|c|c|c|c|c|c|}
\hline \multirow{2}{*}{ Sexual condition } & \multicolumn{5}{|c|}{ Breeds } & \multirow{2}{*}{ Mean } & \multirow{2}{*}{$\mathrm{CV}(\%)$} \\
\hline & Selected Gyr & Selected Guzerat & Unselected Nellore & Selected Nellore & Selected Caracu & & \\
\hline Castrated & $4.74 \mathrm{Aa}$ & 4.91Aa & $5.42 \mathrm{Aa}$ & $4.78 \mathrm{~A}$ & $5.45 \mathrm{Aa}$ & 5.06 & \\
\hline Non-castrated & $4.52 \mathrm{Ba}$ & $4.58 \mathrm{Ba}$ & $5.38 \mathrm{Aa}$ & $5.35 \mathrm{Aa}$ & $4.44 \mathrm{Bb}$ & 4.85 & 14.63 \\
\hline
\end{tabular}

Means in the same row and column followed by different uppercase and lowercase letters, respectively, are different according to the least significant difference test (LSD) $(\mathrm{P}<0.05)$.

Table 4 - Least squares means for the total losses in $\mathrm{kg} / 100 \mathrm{~kg}$ of carcass, from trimmings of the forequarter and short ribs cuts relative to the carcass weight for the different breeds and sexual conditions

\begin{tabular}{|c|c|c|c|c|c|c|c|c|}
\hline \multirow{2}{*}{ Item } & \multicolumn{5}{|c|}{ Breeds } & \multicolumn{2}{|c|}{ Sexual condition } & \multirow{2}{*}{ CV (\%) } \\
\hline & Selected Gyr & Selected Guzerat & Unselected Nellore & Selected Nellore & Selected Caracu & Castrated & Non-castrated & \\
\hline Forequarter & $3.99 \mathrm{a}$ & $3.97 \mathrm{a}$ & $4.22 \mathrm{a}$ & $3.83 \mathrm{ab}$ & $3.49 b$ & $4.17 \mathrm{a}$ & $3.63 b$ & 15.95 \\
\hline Short ribs & $0.80 \mathrm{a}$ & $0.92 \mathrm{a}$ & $0.84 \mathrm{a}$ & $0.90 \mathrm{a}$ & $0.92 \mathrm{a}$ & $0.88 \mathrm{a}$ & $0.87 \mathrm{a}$ & 35.37 \\
\hline
\end{tabular}

Means in the same row for the same factor followed by different letters are different according to the least significant difference test (LSD) (P $<0.05$ ). 
contraction of the sarcomeres, leading to tougher meat (Resende et al., 2002).

There was no difference regarding the final $\mathrm{pH}$ of the carcass among the studied breeds, regardless of the muscle analyzed (Table 5). However, higher $\mathrm{pH}$ values were observed for the non-castrated animals than the castrated ones, which may be attributed to the greater susceptibility of non-castrated animals to stress that may have occurred in the moments before slaughter, promoting release of adrenaline and consequent exhaustion of muscle stores of glycogen. The decrease in $\mathrm{pH}$ is due to the use of these stores and their resultant transformation into lactic acid through anaerobic glycolysis (Garrido and Bañón, 2000; Luchiari Filho, 2000).

It is important to control the $\mathrm{pH}$ because it is related to the color, tenderness, texture, and water-holding capacity of the carcass. The time necessary to achieve the final $\mathrm{pH}$ varies according to the species, rate of cooling, and level of activity prior to slaughter (Resende et al., 2002). The final $\mathrm{pH}$ of the carcass should be between 5.5 and 5.8, indicating meat suitable for processing and consumption (Ciria and Asenjo, 2000; Luchiari Filho, 2000). Therefore, the $\mathrm{pH}$ values measured for top round and sirloin in this study are within the normal range.
With regard to the cooking losses (Table 6), the only studied variable for which an effect was found was the breed. The dripping loss was greatest for the Gyr breed, followed by the Caracu breed. When the total losses and the losses due to evaporation were evaluated, it was evident that the selected and unselected Nellore cattle displayed the greatest losses, while the Guzerat cattle showed the lowest.

Working with the same breeds, Nardon (1998) noted no differences with respect to the total losses, finding an average total loss of $26.03 \mathrm{~kg} / 100 \mathrm{~kg}$ of carcass.

Brondani etal. (2006), evaluating Hereford and Aberdeen Angus steers fed diets with 3.07 and $3.18 \mathrm{Mcal} / \mathrm{kg}$ DM intake, found no effect of breed or energy level $(\mathrm{P}>0.10)$ on the values of evaporation losses. The 10 and $11.02 \mathrm{~kg} / 100 \mathrm{~kg}$ of carcass found by the authors for Hereford and Angus, and 10.37 and $10.64 \mathrm{~kg} / 100 \mathrm{~kg}$ of carcass for the lowest and highest levels of energy, respectively, were lower than these of the present study.

Igarasi et al. (2008), evaluating non-castrated F1 Red Angus $\times$ Nellore steers fed diets containing high moisture corn silage or high moisture sorghum silage, also found no effect of treatment on evaporation losses and total losses. The values of evaporation losses between 14.97 and $15.48 \mathrm{~kg} / 100 \mathrm{~kg}$ of

Table 5 - Least squares means of temperature $\left({ }^{\circ} \mathrm{C}\right)$ and $\mathrm{pH}$ of the commercial cuts of animals according to different breeds and sexual conditions

\begin{tabular}{|c|c|c|c|c|c|c|c|c|}
\hline \multirow{2}{*}{ Item } & \multicolumn{5}{|c|}{ Breeds } & \multicolumn{2}{|c|}{ Sexual condition } & \multirow{2}{*}{$\mathrm{CV}(\%)$} \\
\hline & Selected Gyr & Selected Guzerat & Unselected Nellore & Selected Nellore & Selected Caracu & Castrated & Non-castrated & \\
\hline Temperature in top round & $8.43 \mathrm{a}$ & $7.91 \mathrm{a}$ & $7.56 \mathrm{a}$ & $8.59 \mathrm{a}$ & $8.71 \mathrm{a}$ & $7.62 b$ & $8.87 \mathrm{a}$ & 15.28 \\
\hline Temperature in sirloin & $7.72 \mathrm{a}$ & $7.41 \mathrm{a}$ & $7.44 \mathrm{a}$ & $7.54 \mathrm{a}$ & $8.02 \mathrm{a}$ & $7.28 \mathrm{~b}$ & $7.97 \mathrm{a}$ & 12.54 \\
\hline $\mathrm{pH}$ in top round & $5.68 \mathrm{a}$ & $5.63 \mathrm{a}$ & $5.61 \mathrm{a}$ & $5.77 \mathrm{a}$ & $5.70 \mathrm{a}$ & $5.54 \mathrm{~b}$ & $5.82 \mathrm{a}$ & 4.91 \\
\hline $\mathrm{pH}$ in sirloin & $5.81 \mathrm{a}$ & $5.77 \mathrm{a}$ & $5.81 \mathrm{a}$ & $5.74 \mathrm{a}$ & $5.68 \mathrm{a}$ & $5.62 b$ & $5.91 \mathrm{a}$ & 5.24 \\
\hline
\end{tabular}

Means in the same row followed by different letters differ according to the least significant difference test (LSD) (P<0.05).

Table 6 - Least squares means for the total losses in $\mathrm{kg} / 100 \mathrm{~kg}$ of carcass, and for the shear force $\left(\mathrm{kgf} / \mathrm{cm}^{3}\right)$ of the loin-eye area of the $12 \mathrm{th}$ ribs of animals according to different breeds and sexual conditions

\begin{tabular}{|c|c|c|c|c|c|c|c|c|}
\hline \multirow{2}{*}{ Item } & \multicolumn{5}{|c|}{ Breeds } & \multicolumn{2}{|c|}{ Sexual condition } & \multirow{2}{*}{$\mathrm{CV}(\%)$} \\
\hline & Selected Gyr & Selected Guzerat & Unselected Nellore & Selected Nellore & Selected Caracu & Castrated & Non-castrated & \\
\hline Cooking loss & $11.37 \mathrm{a}$ & $7.80 \mathrm{~b}$ & $8.56 b$ & $8.63 b$ & $10.01 \mathrm{ab}$ & $9.07 \mathrm{a}$ & $9.48 \mathrm{a}$ & 37.06 \\
\hline Evaporative loss & $13.71 \mathrm{c}$ & $14.02 \mathrm{c}$ & $20.29 a$ & $18.06 \mathrm{ab}$ & $16.38 \mathrm{bc}$ & $16.56 \mathrm{a}$ & $16.43 a$ & 26.52 \\
\hline Total loss & $25.08 \mathrm{bc}$ & $21.83 \mathrm{c}$ & $28.86 a$ & $26.69 a$ & $26.39 \mathrm{ab}$ & $25.63 a$ & $25.91 \mathrm{a}$ & 17.82 \\
\hline Shear force & $4.43 \mathrm{a}$ & $3.60 \mathrm{a}$ & $4.57 \mathrm{a}$ & $4.18 \mathrm{a}$ & $4.26 \mathrm{a}$ & $4.39 \mathrm{a}$ & $4.03 \mathrm{a}$ & 31.76 \\
\hline
\end{tabular}

Means in the same row followed by different letters differ according to the least significant difference test (LSD) (P<0.05).

Table 7 - Least squares means of the chemical composition, in $\mathrm{g} / \mathrm{kg} \mathrm{DM}$, of the Hankins and Howe section, of the animals of the different breeds and sexual conditions

\begin{tabular}{|c|c|c|c|c|c|c|c|c|}
\hline \multirow{2}{*}{ Item } & \multicolumn{5}{|c|}{ Breeds } & \multicolumn{2}{|c|}{ Sexual condition } & \multirow{2}{*}{ CV $(\%)$} \\
\hline & Selected Gyr & Selected Guzerat & Unselected Nellore & Selected Nellore & Selected Caracu & Castrated & Non-castrated & \\
\hline Protein & $451.1 \mathrm{~b}$ & $436.2 b$ & $437.8 b$ & $435.7 b$ & $483.4 \mathrm{a}$ & $432.7 b$ & $464.9 \mathrm{a}$ & 7.81 \\
\hline Ether extract & $430.8 \mathrm{a}$ & $442.4 \mathrm{a}$ & $451.5 \mathrm{a}$ & $450.2 \mathrm{a}$ & $394.2 b$ & $448.4 \mathrm{a}$ & $415.2 b$ & 9.42 \\
\hline Ash & $118.1 \mathrm{a}$ & $121.5 \mathrm{a}$ & $120.7 \mathrm{a}$ & $114.1 \mathrm{a}$ & $122.4 \mathrm{a}$ & $118.8 b$ & $119.9 \mathrm{a}$ & 11.67 \\
\hline
\end{tabular}

Means in the same row followed by different letters differ according to the least significant difference test $(\mathrm{LSD})(\mathrm{P}<0.05)$. 
carcass and total losses between 18.50 and $19.48 \mathrm{~kg} / 100 \mathrm{~kg}$ of carcass were similar to the present study.

The characteristics juiciness and tenderness, which are able to provide meats of higher quality, are influenced by handling after slaughter. The results of studies on the losses can be used to guide nutritional management and the crosses in beef cattle. But research results are scarce in the Brazilian literature, and are inconsistent with each other.

With regard to shear force, there were no differences among the studied breeds (Table 6). The shear forces measured in this study ( 3.60 to $\left.4.57 \mathrm{kgf} / \mathrm{cm}^{3}\right)$ may be considered good, given that, according to Oliveira (2000), meat is considered to be tender when the shear force is less than $4.5 \mathrm{kgf} / \mathrm{cm}^{3}$.

According to Koohmaraie et al. (1995), consumers consider tenderness to be the most important component of meat quality. Nardon (1998) measured shear forces of 4.48, 4.73 , and $4.65 \mathrm{kgf} / \mathrm{cm}^{3}$ for selected Nellore, unselected Nellore, and Guzerat cattle, respectively; however, different results were found for the Caracu breed: $3.55 \mathrm{kgf} / \mathrm{cm}^{3}$. Pacheco et al. (2005) did not identify a difference for this characteristic based on a comparison of $5 / 8$ Charolais Nellore and 5/8 Nellore Charolais crossbred cattle. These findings show that well-managed zebu breeds and crossbreeds can produce carcasses with good tenderness and within market standards.

The findings regarding losses due to cooking may also be corroborated in the case of the Caracu breed by the results of the chemical analysis of the HH section (Table 7), which revealed that these animals had more protein and fewer lipids than the other animals. Considering that protein is associated with water in the muscle mass (Berg and Butterfield 1979), it is clear that meat obtained from more muscular animals loses more water during cooking. Furthermore, there was an effect of the sexual condition: castrated animals had less protein and more lipids than non-castrated animals. This pattern was expected, given that castrated animals deposit fat earlier (Robelin and Geay, 1984; Owens et al., 1993).

During growth, variations in chemical composition of the body are influenced by factors such as weight, age, breed, sex, nutritional status, body size and relative growth of carcass tissues (Fontes, 1995; Estrada et al., 1997; Paulino et al., 1999). There were no significant differences detected in the amount of ash for any of the evaluated categories.

The Brazilian cattle herd is composed of a wide range of genetic groups that primarily include the Zebu breeds and their crosses with Bos taurus. Nevertheless, results of Nardon (1998), Jorge et al. (1999) and those of the present study (Table 7), show that it is possible to obtain standardization of meat, with respect to chemical composition, if the animals are fed and handled appropriately.

\section{Conclusions}

In general, no large differences between Zebu breeds and the Caracu cattle in terms of the total trimming losses in the primary cuts (forequarters, short ribs, and pistol style cut) are observed, and there are no detectable differences in the shear forces between breeds. The meat from bulls exhibit higher $\mathrm{pH}$ values than that from steers, demonstrating a greater propensity for the former animals to experience stress prior to slaughter.

\section{References}

Berg, R. T.; Butterfield, R. M. 1979. New concepts of cattle growth. Sydney University, New York.

Brondani, I. L.; Sampaio, A. A. M.; Restle, J.; Alves Filho, D. C.; Freitas, L. S.; Amaral, G. A.; Silveira, M. F. and Cezimbra, I. M. 2006. Composição física da carcaça e aspectos qualitativos da carne de bovinos de diferentes raças alimentados com diferentes níveis de energia. Revista Brasileira de Zootecnia 35:2034-2042.

Ciria, J. and Asenjo, B. 2000. Factores a considerar en el presacrificio y postsacrificio. p.19-47. In: Metodología para el estudio de la calidad de la canal y de la carne en rumiantes. Cañeque, V. and Sañudo, C., eds. Instituto Nacional de Investigación y Tecnología Agraria Y Alimentaria, Madrid.

Costa, R. S.; Henry, F. C.; Ferreira, K. S.; Valle, F. R. A. F. and Quirino, C. R. 2012. Characterization of rigor mortis of longissimus dorsi and triceps brachii muscles of male cattle carcasses. African Journal of Biotechnology 11:8127-8132.

Estrada, L. H. C.; Fontes, C. A. A.; Jorge, A. M.; Guimarães, M. M.; Freitas, J. A. and Queiroz, A. C. 1997. Exigências nutricionais de bovinos não-castrados em confinamento. 1. Conteúdo corporal e exigências líquidas de proteína e energia para ganho de peso. Revista Brasileira de Zootecnia 26:575-583.

Fontes, C. A. A. 1995. Composição corporal, exigências líquidas de nutrientes para ganho de peso e desempenho produtivo de animais zebuínos e mestiços europeu-zebu. Resultados experimentais. p.419-455. In: Anais do Simpósio Internacional sobre Exigências Nutricionais de Ruminantes. Universidade Federal de Viçosa, Viçosa, MG, Brasil.

Garrido, M. D. and Bañón, S. 2000. Medida del pH. p.145-157. In: Metodología para el estudio de la calidad de la canal y de la carne en rumiantes. Cañeque, V. and Sañudo, C., eds. Instituto Nacional de Investigación y Tecnología Agraria Y Alimentaria, Madrid.

Hankins, O. G. and Howe, P. E. 1946. Estimation of the composition of beef carcasses and cuts. Technical Bulletin, 926. United States Department of Agriculture, Washington, D.C.

Jorge, A. M.; Fontes, C. A. A. and Paulino, M. F. 1999. Composição corporal de bovinos de quarto raças zebuínas, abatidos em diferentes estádios de maturidade. Revista Brasileira de Zootecnia 28:388-394

Koohmaraie, M.; Wheeler, T. L. and Shackelford, S. D. 1995. Beef tenderness: regulation and prediction. p.4A-14A-20. In: Meat 95: Australian Meat Industry Research Conference. Brisbane, CSIRO.

Luchiari Filho, A. 2000. Pecuária da carne bovina. 1.ed. R. Vieira Gráfica e Editora, São Paulo.

Nardon, R. F. 1998. Seleção de bovinos para desempenho: composição corporal e características de carcaça. Tese (D.Sc.). Universidade Estadual Paulista, Jaboticabal. 
NRC - National Research Council. 1996. Nutrients requeriments of beef cattle. 7th ed. National Academic Press, Washington, D.C.

Igarasi, M. S.; Arrigoni, M. B.; Hadlich, J. C.; Silveira, A. C.; Martins, C. L. and Oliveira, H. N. 2008. Características de carcaça e parâmetros de qualidade da carne de bovinos jovens alimentados com grãos úmidos de milho ou sorgo. Revista Brasileira de Zootecnia 37:520-528.

Izquierdo, M. M.; Amin, V.; Wilson, D. E. and Rouse, G. H. 1996. Models to predict intramuscular fat porcentage in live beef animals using real time ultrasound and image parameters: report on data from 1991-1994 A.S. Leaflet R1324. Available at: <http://www. extension.iastate.edu/Pages/ansci/beefreports/asl-1324[1].pdf.> Acessed on: July 11, 2000.

Oliveira, A. L. 2000. Maciez da carne bovina. Cadernos Técnicos de Veterinária e Zootecnia (33):7-18.

Owens, F. N.; Dubeski, P. and Hanson, C. F. 1993. Factors that alter the growth and development of ruminant. Journal of Animal Science 71:3138-3150.

Pacheco, P. S.; Restle, J.; Da Silva, J. H. S. Brondani, I. L.; Pascoal, L. L.; Alves Filho, D. C.; Arboitte, M. Z. and Freitas, A. K. 2005. Composição física da carcaça e qualidade da carne de novilhos jovens e superjovens de diferentes grupos genéticos. Revista Brasileira de Zootecnia 34:1691-1703.
Paulino, M. F.; Fontes, C. A. A. and Jorge, A. M.; Gomes Júnior, P. 1999. Composição corporal e exigências de energia e proteína para ganho de peso de bovinos de quatro raças zebuínas. Revista Brasileira de Zootecnia 28:627-633.

Razook, A. G.; Figueiredo, L. A.; Cyrillo, J. N. S. G.; Pacola, L. J.; Bonilha Neto, L. M.; Trovo, J. B. F.; Ruggieri, A. C. and Mercadante, M. E. Z. 1997. Prova de ganho de peso: normas adotadas pela Estação Experimental de Zootecnia de Sertãozinho. Boletim Técnico, 40. Instituto de Zootecnia, Nova Odessa.

Resende, F. D.; Alleoni, G. F.; Razook, A. G. Figueiredo, L. A.; Oliveira, H. N.; Arrigoni, M. B.; Queiroz, A. C.; Gesualdi Júnior, A. and Faria, M. H. 2002. Curvas de $\mathrm{pH}$ e temperatura durante o processo de resfriamento da carcaça de animais das raças Nelore e Caracu submetidos a diferentes regimes alimentares na fase de terminação. cd-rom. In: Anais da 39a Reunião Anual da Sociedade Brasileira de Zootecnia. Sociedade Brasileira de Zootecnia, Recife.

Robelin, J. and Geay, Y. 1984. Body composition of cattle as affected by physiological status, breed, sex and diet. p.525-547. In: Herbage nutrition in the subtropics and tropics. Gilchrist, F. M. C. and Mackie, R. I., eds. Science Press, Johannesburg.

Silva, D. J. and Queiroz, A. C. 2002. Análise de alimentos (métodos químicos e biológicos). 3.ed. UFV, Viçosa, MG, Brasil. 